\title{
Omkring en Kodak
}

\author{
Peter Altenbergs genremontager
}

\author{
Marianne Ping HuANG
}

Er ist kein Lyriker, denn er hat keine Form. Er ist kein Epiker, denn er hat keine Handlung. Er ist kein Philosoph, denn er hat kein System. Seine Gedanken sind barock, sein Stil salopp, seine Rhetorik ist überheizt. Und im Leben ist er ein Narr. ${ }^{1}$

Man kan læse wiener-forfatteren Peter Altenberg (egl. Richard Engländer, 1859 - 1919) som en parabel for den kultur, han registrerede i sine korte prosastykker. Han var en øjebliks-fanger og impuls-fisker i et sjæle- og realrum, gennemstrømmet af nervøs energi.

Forestillingen om usynlige, men ikke desto mindre yderst virkningsfulde energier, som på en eller anden måde virker ind på individet, er formodentlig fantasmet i det 19. århundredes sidste tyve år. ${ }^{2}$

Energifantasmet ved århundredskiftet sporer-Christoph Asendorf i Batterien der Lebenskraft gennem elektriciteten som metafor. Litterært finder man både elektricitet som centralt teknologisk fænomen og som et gennemgribende diskursivt billede, der også slår igennemi en række af samtidens videnskabsdiskurser. Asendorflæser Peter Altenbergs korte prosa som eksempler på, at den uhåndgribelige energi får litterær og tekn(olog)isk form. Prosastykkerne forstås da - under henvisning til sætningstegnenes særlig grafiske effekt $-i$ en sammenligning med morsesystemet, 
hvilket stemmer overens med Altenbergs karakteristik af sin prosa som „sjælens telegramstil“:

For Altenberg er telegramstilen ingen abstraktion [...] men en mulighed for at fremstille komprimerede sjælelige energier ved hjælp af den afkortede, impressionistiske antydning og det telegrafiske tegnsprog. Antydningen af sjælelige strømme ved morsetegn er også et middel til - som han siger andetsteds - at bevare "livsenergierne", dvs. „kraften i vores nervesystem", fra sønderdeling gennem grov sproglig konkretion og samfundsmæssig distraktion. ${ }^{3}$

Altenbergs kortform er ganske rigtig udspændt mellem det eksakt indrammede og noget endnu skjult. Hvert prosastykke, hvoraf ganske mange netop excellerer i stregsystemer og udråbstegn, kan læses som et telegram. Men stykkerne formidler sjældent den umiddelbare øjeblikssansning, som Altenberg - der karakteriserede sig selv som udstyret med en "patologisk hjerne", altså som et nervøst, æstetisk apparat - forstod sin form ud fra. Der er tværtimod tale om yderst raffineret monterede billeder og en lige så nøjagtig pakning af sætningsmaterialet, hvis samlede effekt måske, måske slet ikke, er øjeblikssansningen. Denne indtræder nemlig som en biomstændighed ved den omhyggelige montage, hvis grundelement synes at være tableauet, sådan som Roland Barthes forstår det $\mathrm{i}$ en analyse af bl.a. Eisensteins filmiske montage:

Tableauet (billedkunstnerisk, dramaturgisk, litterært) er et rent udskåret segment med tydelig definerede rammer, irreversibelt og irreducerbart; alt som omgiver det henvises til intethed, forbliver ubenævnt, mens alt som vinder indpas i det forlenes med essens, lys, synlighed. 4

Hos Altenberg er tableauet i sin egenskab af klart defineret segment en formel fællesnævner for hans behandling af de genrer, hvorigennem sansningen tilnærmes. Tableauerne er synlighedens form, og ved det som kommer fuldt til syne lader Peter Altenbergs prosastykker sig forstå som aftryk af århundredskiftets wiener-kultur; som øjebliksregistreringer og æstetiseret poseren. Men stykkerne kan også ses, høres og læses i deres monta- 
geform, der altså reflekterer en række konventioner eller genrer, betingelserne for at gestalte synlighed, om man vil. Peter Altenbergs korte prosa er altså sin korthed til trods en prosamontage, sat sammen af tableauer eller segmenter, som ofte refererer til de kendte kortformsgenrer. Segmenteringen af den korte form i forbindelse med Altenbergs pointeringer af sin prosas billedlighed indbyder til en forståelse af sammenstykningen som en montage af litterære billeder, der ikke ganske bekræfter opfattelsen af kortformens impressionistiske karakter.

\section{Mønstre uden værdi}

\section{- mellem feuilleton og parabel}

„Der hæfter sig det ulyksalige ved de ting jeg skriver, at de altid bliver betragtet som små prøver, og så er de dog hvad jeg overhovedet er i stand til at præstere",5 skriver Peter Altenberg til kollegaen Arthur Schnitzler i juli 1894. Senere i brevet omtaler Altenberg sin prosa som „,værdiløse mønstre", og tilføjer: „hvoraf der ikke altid følger nogen vare".

Det mønster-begreb Altenberg forbinder med sine små prosastykker lader forstå, at den litterære form kan opfattes som et industrielt mønster eller en matrice; en form, der ikke er udfyldt og som ikke med sikkerhed 'leverer varen' - glimtet af en øjeblikssansning. "Jegsøger" havde Schnitzler kaldt Altenberg. Mere end at søge et eget eller et digterisk jeg i sin prosa synes Altenberg at have søgt udløsningen af det moment, hvor et hvilket som helst jeg krydser sin egen sansning - øjeblikket hvor 'noget' træder distinkt sanset i forgrund.

Ser man på Altenbergs genrearbejde - altså på det reservoir af former han betjente sig af i sin korte forms montager - er der tale om dialoger, skitser, sketches, genrebilleder, rejsebreve, aforismer og maksimer. Ingen af dem anvendes dog dækkende, alle vrides en smule gennem segmentets tydelige rammer, altså gennem tableauisering. Der er over hver genre, som prøves i de korte stykkers montage, noget alt for tydeligt billedmæssigt, noget scenisk overkodificeret.

Altenbergs korte prosa forbinder sig imidlertid også mere signifikant med enkelte af kortformens genrer. Således kan pro- 
sastykkerne sammenlignes med den samtidige udvikling af feuilletonen til en lille kulturel scene for den velturnerede, impressionistiske skribent. Som sådan spillede feuilletonen en stor rolle i gestaltningen af århundredeskiftets kulturrum, ikke mindst i Wien. Feuilletonen var - og ér, hvor den endnu eksisterer - et stykke kort dagbladsprosa, som især fandt sin form med udviklingen af omnibusavisen. Det franske 'feuilleton' kommer af 'lille blad' og hentyder bl.a. til feuilletonens korthed og lette stil, hvor ikke mindst skribent-jeget kunne skabe sig sin egen scene og jeg-positur i et fluktuerende kulturrum. Feuilletonen og Altenbergs korte prosa læst under denne optik - er en genre, som er eksemplarisk for metropolens højtrykscirkulation af kultur. Altenbergs prosastykker vidner i såvel deres elokvente omsætning af tilsyneladende øjebliks-registreringer, som i deres grafiske poseren og sceniske karakter om feuilletonens journalistiske kortform:

Feuilletonisten, en kleinkunstner i zier-former, arbejdede med disse skjulte enkeltheder og episoder, som i så høj grad tiltalte det 19. århundredes smag for det konkrete. ${ }^{6}$

Altenbergs korte prosa kan - læst som impressionisme og i lighed med feuilletongenren - siges både at tale ind i metropolens selvgenererende kulturrum, at gestalte dette kulturrum gennem sin registrering af dets stemmer og steder, og at bekræfte træk ved kulturrummet netop gennem sin impressionisme, hvor genstanden ophæves i stemning.

Men prosastykkerne er mere end momentane stykker af en scenisk kultur. For dette taler montage-karakteren og montagens effekt; det træk, som Altenberg omfattede ved benævnelsen "værdiløse mønstre", hvis man vælger at læse 'mønstret' som sammenstykning og det 'værdiløse', ikke som stykkernes lette øjeblikskarakter, men som en formgivning der forbereder noget andet. Montagen bliver da en nødvendig, men ikke tilstrækkelig præmis for at 'noget' kan vise sig. Altenbergs korte prosa forbinder sig således også signifikant med parablens kortform; ganske vist ikke med en klassisk parabel, som bærer sin udlægning i sig, 
men med en moderne parabel, som udkaster et billede eller en konstellation af billeder til en ubestemt tydning:

Denne parabel-type sammenligner ikke det ene med det andet, men peger blot $i$ en given bevægelsesretning. ${ }^{7}$

Således forbinder Altenbergs kortform sig præmaturt med en udvikling af feuilletonen, som også blev feuilletonens afvikling som impressionistisk dagbladsgenre. Denne udvikling ses hos feuilletonister som Ernst Bloch, Siegfried Krakauer og Walter Benjamin, som i tyverne og trediverne viklede feuilletonen ud af kulturrummets selvcirkulerende inderlighed og af det lille kulturjournalistiske tableau udviklede formen Denkbild. 'Tankebilledet' ligger mellem den skønlitterære kortprosas anskuelighed, essayets refleksion og den filosofiskebegrebslighed ${ }^{8}$. Almut Todorow påpeger i en undersøgelse af denne udvikling, ${ }^{9}$ at feuilletonen med tankebilledet når sit formmæssige højdepunkt, som samtidig rykker genren ud af det medium, omnibusavisen, som den var opstået af. Det sker, fordi tankebilledet ikke som feuilletonen etablerer et selvbekræftende forhold mellem begivenhed og kulturrummets almindelige distraktion ved at omsætte øjeblikkets aktualitet i skribentens kolorering. Tankebilledets skribent afstod tværtimod fra at være publikums æstetiske kritiker-apparat og trådte udover kulturscenens rampe; på en uvis afstand.

Noget lignende kan spores i Altenbergs spidse behandling af den "samfundsmæssige distraktion". Montagens præcise segmentering og hurtigheden i prosastykkernes skiften klipper sig gennem billedets stemning. Den æstetiske suggestion opbygges, for lynsnart at brydes. Genrene både afkortes og sammenstilles ved deres tydelige brudflader, sådan at montagen vibrerer af en retningsløs bevægelse, som bringer Altenbergs prosa på en uvis afstand af såvel en blot og bar iscenesættelse af storbyens folkeliv som af en målrettet kritik af metropolkulturens poserende selvbekræftelser. 


\section{Kodak}

Altenbergs montage viser, at prosastykkernes stemninger synes at bero i noget nært sanset, og at de dog, med ét slag, kan rykke andre fjernere scener ganske tæt på, hvorved den suggestive stemning i de fuldt opbyggede tableauer afslører sig som genrearbejde, som mønstre. Det er derfor ikke overraskende, at Altenberg prioriterer billedet og dets opbygning langt over det berettende. Stykkerne har ganske vist bevægelse eller forløb, men snarere end at være fortællende, bevæger prosaen sig ved at skifte perspektiv, mellem for- og baggrund - mellem sansning og forestilling, mellem billede og sprog, mellem sprog og ramme.

I et kort, proklamatorisk essay, „Kunst” (1905), fremstiller Altenberg sin kunst under en overordnet, æstetisk bestræbelse, der bekræfter dette:

Vi vil formæle kunsten, dette exceptionelle, med hverdagen. Damen R.H.'s hånd er et guddommeligt kunstværk. Vi fotograferer den. Eller barnet R.O. som leger i parken. Eller den gamle aristokrat, som krydser gaden. Tilværelsens rigdom, rykket nær på for dem, hvis nødvendige travlhed forhindrer dem $\mathrm{i}$ at opleve den. 10

Her beskriver Altenberg sin prosa som repræsentationer af livsudsnit - ofte af netop det rastløse liv, hvis deltagere ikke kan fokusere disse udsnit, men hvis detaljer Altenberg vil rykke i fokus, bringe i forgrund: metropolens ganske profane foretagsomhed, bevægelser over gader, leg i parker, hænder på skranker, borde eller gelændere. Derfor er det ikke tilfældigt at disse billeder sammenlignes med fotografiet.Herved henvises der til prosabilledets realisme på samme måde som der ved det fotografiske billede hæfter en realisme. Sådan set synes prosabilledet ikke at bringe kunsten til livet, men hverdagen til sanserne - tilværelsens øjeblikke erhverves, som Altenberg skriver, „, med en Kodak i hånden".

Spørgsmålet man kan stille, er om Altenbergs prosastykker er fotografiske i snapshottets forstand eller om de i sig selv er en art fotografiske objekter. For er det fotografiske billede opbevaringen af et øjeblik i tilværelsen, eller er det erhvervelsen af et bil- 
lede? Rune Gade fremstiller i Staser fototeoretikeren André Bazins begreb om fotografiets realisme og objektivitet således:

Den lighedsrelation mellem objektet og dets billede, som Bazin lokaliserer i den fotografiske proces, er ikke noget identitetssammenfald i naiv, magisk forstand. Bazin forveksler ikke objektet og dets billede, men fremhæver det fysiske aftryk, som den fotografiske teknik afstedkommer. Når han vælger at bruge ordet objektiv (fransk objectif), er det naturligvis ikke mindst på grund af dets dobbelte betydning. Ordet 'objektiv' refererer således henholdsvis (fototeknisk) til den optiske linse, der tegner det fotografiske billede, og (filosofisk) til den ydre, materielle virkelighed, det man er stillet overfor. [...] Objektivet er den instans, der formidler den ydre virkelighed som noget andet for os, det er den instans, der bryder den synlige virkeligheds lys for os, som var det en kode, der krævede dechifrering. ${ }^{11}$

Under henvisning til Altenbergs Kodak som et poetologisk emblem for det, man kunne kalde prosastykkernes parabelhenvisning til en flygtig objektivitet, må man sige at stykkerne ikke er objektive i fotografisk forstand, eller at den fotografiske objektivitet indtræder pludseligt - og ikke altid - som en vare, der i lykkelige øjeblikke slipper matricen.

Hvor jeg ovenfor anførte, at Altenberg i sin prosa søgte jeget i det øjebelik det krydsede sin egen sansning, kunne man med Kodak-billedet sige, at Altenbergs genre-montager er det objektiv - de forhåndenværende tekniske virkemidler - som han bringer $i$ anvendelse for at fremkalde en mulig, genretraderende objektivitet. Det var ikke så ligetil at stille skarpt i deț selvcirkulerende kulturrum, som Altenberg skrev sin prosa:

Hans skitser - virtuose psykogrammer fra et samfund dømt til undergang - skal forstås som fotografier af det virkelige liv, taget med kærtegnende øjne og fremvist som besværgelse. De ligner avisbilleder med scener fra borgerskabet eller proletariatet, titlerne ligner ofte billedtekster (Blumen-Korso; Im Volksgarten; Der Landungssteg; Spätsommer-Nachmittag; Herbstabend). 12

I citatet ses vanskeligheden ved at genrebestemme billedligheden i Altenbergs prosa - den ligger netop mellem noget iøjnefaldende objektivt og noget ligeså iøjnefaldende genre-bestemt. Der 
tales om fotografier, avisbilleder eller i modsætning hertil, hvilket stykkernes titler mere end antyder, om malerkunstens genrebilleder. Prosastykkerne ligger mellem det registrerende og det repræsenterende.

Altenbergs korte prosa er altså billedlig, men billedkarakteren findes snarere i forholdet mellem ramme, genre og fokus end i en impressionistisk ekphrasis over snapshots af folkeliv. Hvis Altenberg 'fotograferer' noget i det direkte én-til-én-forhold mellem objekt og billede, som antydes i essayet "Kunst", er det genrene han skriver og monterer igennem. Prosaen er ikke - som Bazin hævdede om fotografiet - teknisk gennemtrængt af virkelighed, tværtimod må optikken konstrueres. Virkelighedens lys er præcis "en kode som kræver dechifrering", og Altenbergs afsøgning synes at vise, at chifrene kun fremkaldes i korte, næppe synlige øjeblikke.

\section{Fugl Øje Slæbepram}

„Fúglen pirol“ (,Der Vogel Pirol“) trykkes i Peter Altenbergs debutsamling, Wie ich es sehe, som udkom i 1896; ikke på forfatterens, men på Arthur Schnitzlers og Karl Kraus' initiativ. Sammen med stykket "Im Volksgarten", (også fra Wie ich es sehe) er "Fuglen pirol" et af Altenbergs mere kendte stykker, og det lille stykke - 23 helsætninger - viser da også alle de altenbergske træk.

"Fuglen pirol“ gennemspiller flere kortforms- og billedgenrer i en montagebevægelse mod et næppe synligt fokus, som lynhurtigt flyttes og sender prosaen tilbage i et selvcirkulerende rum. I andre stykker vælger Altenberg at gennemklippe ét centralt tableau med kontrastive genrer. Det gælder fx ovennævnte „Im Volksgarten", hvor en montage mellem dialog og indre monolog klippes scenisk sammen omkring begæret efter en blå ballon. Eller stykket "Am Lande", hvor en dames indtryk af havet i skumring formidles i ren dekadent palet, monteret med en eksakt regi af skumringens forløb i minutter og med ægtemandens indre monolog og dæmpede samtale med stuepigen. Hvor montagen i disse stykker poder det centrale motiv og dets udfoldelse med en uvis distance, der rykvis blænder op og ned for table- 
auets iscenesatte karakter, falder "Fuglen pirol" $\mathrm{i}$ to forskellige scener: et lille genrebillede af dæmringen, hvor pirolen sætter $i$ at synge, og en dialog mellem en dame og en herre, som refleksivt nærmer sig pirolen som symbol. Hele stykket er gennemtrængt af gentagelser, som fungerer rytmisk. Gentagelserne gør pirolmotivet til et lydbillede, mens dialogen mellem damen og herren får grafisk karakter ved liniebrud og Altenbergs karakteristiske sætningstegn.

Første tableau i „Fuglen pirol“ rammesættes i tre korte sætninger, hvor tid, sted og stemning - genrens filter - angives: Dæmring i Prateren, træerne dufter; landskabsidyl, miniature. Miniaturen udfoldes som et lydligt, prosarytmisk tableau gennem de følgende fem sætninger: pirolen begynder sin sang med morgenens komme. I stykkets sidste femten sætninger udfoldes anden scene, dialogen, som (metapoetisk) drejer sig om muligheden for at komme tæt på livet. Dialogen udvikles ganske vist i retning af pirol-motivet, som gentages parafrasisk, men tableauet eller genren står antagonistisk til pirolens sang: den kan i sin gestiske knaphed læses som en anekdote om moderne distraktion.

"Endnu er det nat i Prateren. Nu gråner det. Indtrængende dufter pilene og birkene, blødt olieagtigt." Vi er i Wiens Prater, i parkens miniatureverden, som er både indfældet i og adskilt fra byens foretagsomhed, og vi er der på et tidspunkt hvor denne travlhed endnu ikke kontrasterer den indrammede idyl. Både tid og sted har intervallets karakter. Dæmringsøjeblikket registreres i lysets stigende gråtone, men især gennem en sekundvis fremrykning mellem "Endnu" og "Nu“. Denne staccato resumeres i sidste sætnings ",indtrængende", og kontrasteres af stemningens "blødt olieagtig". Rytmen i de tre sætninger underbygger det indtrængende fremfor det stemningsfulde. Den præcise bevægelse mellem "Noch ist es" og "Nun wird es" tilsvarer i tidsadverbier og tempusskift "Eindringlich", som er rykket frem i sidste sætning, således at ordet ved sin syntaktiske vægt ganske vist balancerer sætningens udmunding i stemningens hinde, "sanftölig", men især intensiverer indramningens øjeblikskarakter: det 
afventende 'endnu', det registrerende ' $n u^{\prime}$ ', det intense 'indtrængende', der slutteligt - næsten påtrængende - åbner for reveillens lyd.

Pirolens sang, der afstedkommes af dæmringen, gøres lydlig gennem syntaktisk præcision og gentagelser. Fuglens sang kaldes reveille - den vækker og ordet 'reveille' skanderer prosaen, hvis indtrængen beror netop på gentagelsen og de „korte afbrydelser", som er reveillens rytme. De to sætninger, „Fuglen pirol begynder at blæse reveille, naturens reveille! Med korte afbrydelser blæser den reveille", lader 'reveille' lyde som en triol.

Den treleddede præcision gentages da i tableauets resumerende sammenskrivning af ramme og fuglesang: tre sætninger hvis normalstillede syntaks og indhold falder sammen med en afsvækkelse af reveillens pludselige gennemslag - „Alt, alt er endnu stille og gråt, birke og pile dufter indtrængende, og fuglen pirol blæser med korte mellemrum reveille." Det „indtrængende" står nu syntaktisk afladt, stemningsfuldt. Gentagelsens intensitet har lagt sig og flyder yderligere ud i tableauets lukning, "Uafladeligt", som står parallelt til „blødt olieagtigt" i de indledende sætninger. Tableauets øjeblik udspændes mellem gentagelsens indtrængende rytme og en beskrivelse af gentagelsen, Uafladeligt.

Mens pirolens sang i dæmringen er et billede i lyd, tilføjes en refleksion over billedet $i$ dialogen mellem en dame og en herre. Damen og herren er stemmer, ikke karakterer. Her er ikke noget udfoldet sjæleliv, men punktuelle og ufærdige positurer, understreget af sætningsudgangene "---“ eller „?!?". Psykologisk står tableauet i negativ. Scenen og tiden er abstrakt, etableret ved en kulisseskabende præteritum - „Damen sagde engang“ - der mere end noget andet viser, at pirol-billedet er monteret med dialogen. Tempusskiftet angiver et abrupt temposkift, en brudflade. I dialogen skaber baggrundstiden en kontrast til scenens dramatisk grafiske positurer; kontrasten eksponerer en indre, genremæssig spænding i dialogstykket. Det er generelt og dog dramatisk specifikt. Talen synes at være hørt eller endda aflyttet, altså registreret, men udfoldes i sin sproglige og genremæssige kodifi- 
cering mellem reflekterende tydning og en moderne parabels nøgternhed.

Dialogens indhold indtil 21. sætning reflekterer pirol-motivet: Pirolens sang udlægges af herren som, ét af disse 'Kodakmomenter', hvor øjebliksoplevelsen danner sluse for punktuel erfaring. Hér figureres det fotografiske som snapshot, „Fra sådanne skjulte vinkler, som fra et baghold, kan man komme over livet". Imidlertid er pirolens indtrængende sang ikke formidlet lydlig intenst, som i stykkets første tableau. Ganske vist finder vi i herrens resumerende beskrivelse også gentagelses-figuren, men både resume og gentagelsen "gamle, gamle" suggererer snarere det "blødt olieagtige", en ubrudt, hindeagtig stemning, som parafraserer pirolen som symbol og genrebillede.

I 22. sætning af „Fuglen pirol“ punkteres hinden. Fra herrens beskrivelsen af dæmringen, "[s]tadig lysere og lysere bliver det", følger "og de opspilede øjne bliver helt synlige". Sætningen er deiksisk uforbundet, øjnene svæver frit, selv om de står som en del af herrens replik. Dialogen og dens parafraserende indfældning af pirolens sang, der fungerer som en overblænding, viser sig nu at være mediet for et moment, der både er en del af talen og passerer uregistreret gennem den. Selve dialogen fremstår således som repræsentation af den rene foretagsomhed, som snakkens støjkilde i den vågnende by, men fungerer også som sluse eller 'skjult vinkel' for en pludselig tilsynekomst.

"Stadig lysere og lysere bliver det", i denne sætning er dæmringen stadig og dog ikke længere herrens regi til fuglebilledet, den er også lysets vej ind i Kodak. Vi er på vej ind i objektivet, ind i stykkets blænde og ind i perspektivpunktet i Peter Altenbergs fotografiske prosa: „Objektivet er den instans, der formidler den ydre virkelighed som noget andet for os, det er den instans, der bryder den synlige virkeligheds lys for os, som var det en kode, der krævede dechifrering." Synet deler sig nu, på den ene side i det næppe synlige, i retning af noget optisk ubevidst, fra de opspilede øjne til Donaubredden, hvor slæbepramme afventer dagens begyndende dont, og på den anden side følger vi damen til- 
bage til Prater-scenen, til stykkets begyndelse som er et forlængst passeret moment - „Lad os gå til fuglen pirol“.

Pirolens sang i prosaens rytmiske eksponering og sangens indtrængen i øret repeteres teknisk i kamerablikket og præcis hvor pirolen, som ingen ser, får billedlig karakter i herrens stemningsmaleri, åbner stykket sig som et objektiv. Også her trænger noget ind - de foreliggende objekter, prammene, bliver momentant synlige. Det centrale billede, det egentlig fotografiske moment $i$ "Fuglen pirol", er disse to sætninger: "de opspilede øjne bliver helt synlige. Ved bredden ligger sorte enorme slæbepramme, ventende på dagens virke med deres rummelige kræfter". Sætningerne viser en moment-sansning af noget ganske profant foreliggende, fra en skjult eller endda overset vinkel.

Fra dette moment - som er varen, der ikke altid følger af Altenbergs montage - kan resten af "Fuglen pirol" læses som en matrice, en støbeform. I montagen mellem det lydmalende pirolmotiv og den stemmeeksponerende dialog lægges en fond af elaboreret stil og dekorativ omhu, der udfælder de to stykker som afgrænsede segmenter, som monterede tableauer. Der er tydeligt tale om en miniature og en sketch. Men i sammenstillingen af de klart definerede tableauer og i overblændingen mellem de to segmenter, som finder sted i herrens parafrase af pirol-billedets stemning etableres den objektive magi, som fremkalder billedet af noget optisk ubevidst. 


\section{Noter}

1. Egon Friedell: Ecce poeta, Berlin 1912. Citeret efter Stefan Niehaus:

Das Prosagedicht im Wien der Jahrhundertwende, Berlin-New York 1986, p. 26.

2. Christoph Asendorf: Batterien der Lebenskraft, Berlin 1984, p. 119

3. Op. cit. p. 120

4. Roland Barthes: „Diderot, Brecht, Eisenstein", in: Image, Music, Text. Glasgow 1977, p. 70.

5. "Brief an Arthur Schnitzler. Juli 1894", in: Die Wiener Moderne, Stuttgart 1990, p. 428

6. Carl E. Schorske: Wien. Geist und Gesellschaft im Fin de Siècle, Frankfurt a.M. 1982, p. 8.

7. Walter Höllerer: "Die Kurze Form der Prosa“, In: Akzente, 9. Jahrgang, Frankfurt a.M. 1962, p. 238. Walter Höllerer bestemmer i artiklen den korte prosa ("die Kurzgeschichte") i modsætning til bl.a. den klassisk tyske novelle, men også til andre kortformer som anekdoten, vitsen, fablen, den klassiske parabel, skitsen, feuilletonen og prosadigtet.

8. Cf. Dorthe Jørgensens: „Konstruktion af tankebilledet". Efterskrift til Walter Benjamin: Ensrettet gade, Århus 1992

9. Almut Todorow: Das Feuilleton der Frankfurter Zeitung in der Weimarer Republik. Zur Grundlegung einer rhetorischen Medienforschung, Tübingen 1996

10. in: Die Wiener Moderne, p. 505

11. Rune Gade. Staser, Århus 1997, pp. 25

12. Kindlers Literatur Lexikon, Bd. 23, p.10216. Zürich 1974. 


$$
\text { - }
$$

